\title{
Editorial: Who Belongs?
}

\author{
Arthur Muliro $^{1}$
}

Published online: 29 January 2020

(c) Society for International Development 2020

This journal issue seeks to create a conversation about the subjects of identity and citizenship; two separate but interrelated concepts that continue to afflict the lives of many people around the world, yet paradoxically, are taken for granted by very many more people in the world. A fundamental premise that is central to these two concepts is that they are used to determine belonging - in a social and legalistic terms.

Two decades into this new century, it might be considered moot to be having a discussion about identity and citizenship, particularly given the challenges that we collectively face, notably a growing ecological crisis coupled with an uncertain economic trajectory for the period to come. However, as we will try to argue in this editorial, and as the authors in this issue have highlighted, the questions of identity and citizenship are central to these challenges and that we cannot take the simplistic route of dismissing them as being irrelevant or out of hand.

That the questions around belonging have become sharper and more abrasive in recent years is not necessarily surprising: many countries' politics and economics have become more exclusionary and perhaps it thus becomes necessary to mark territory more explicitly by defining who is in and who remains out. As the ecological crisis compounds itself and with a looming threat of resource scarcities on the horizon, reviving old dichotomies or creating new ones has once again become a preferred way for many to engage in public discourse about what matters. But perhaps more important is the fact that our politics has become hostage to and is dependent on the persistence of a climate (or climates) of fear. Thus, the establishment of bogeymen and chimeras has become a (winning) modus operandi for today's modern politician. To focus on building hope, encouraging community and celebrating humanity is perhaps being seen as too 'soft' and inadequate to face up to the problems of the day. One

Arthur Muliro

amuliro@sidint.org

1 Society for International Development, Rome, Italy just has to reference recent political campaigns in virtually any country of the world to understand the extent to which politics has become nasty and dependent on vilifying and denigrating 'the other'.

The fact is that we are living through a period of rapid and transformative change and an inevitable journey companion of this change is the fact that lives and livelihoods are being upended - some for better, but for the majority, this has introduced new uncertainties and anxieties which have in turn generated fears that have been poorly managed and often hijacked for narrow and divisive agendas. However, as John Powell reminds us, 'anxiety does not have to turn into loss and fear' (Powell 2020).

Furthermore, the pervasive and unchecked reach of social media has allowed for shadowy forces and actors to stoke fears, peddle untruths and reshape reality in ways that would have hitherto been unimaginable. We too, perhaps unwittingly, play our part in amplifying and distributing unverified facts and find echo-chambers that assuage our fears and tell us what we would like to hear. Thus, we rarely go out of our way to seek to dialogue with those who might hold ideas different from ours. We go to war in our virtual spaces, leaving little room for learning or appreciating from others. We are then surprised when the outcomes of civic processes lead us in directions we least expected.

As Lydia Polgreen warned us in her article:

We are currently facing a new systemic collapse, one that has built far more swiftly but poses potent risks for all of humanity: the collapse of the information ecosystem. We see it play out every day with the viral spread of misinformation, widening news deserts and the proliferation of fake news. This collapse has much in common with the environmental collapse of the planet that we're only now beginning to grasp, and its consequences for life as we know it are shaping up to be just as profound...

The collapse of the information ecosystem has already wreaked havoc on our political systems. It has undermined democratic elections. It has shaken basic trust 
in institutions. It has left us with a world in which anyone is free to choose their own facts. It threatens to fundamentally destabilize the existing world order (Polgreen 2019).

Yet, and in spite of warnings about the havoc we are unleashing on our societies, the temptation to continue digging ourselves deeper into a fix is almost hard wired into ourselves and our processes. Playing divisive politics is what is needed to win elections today and virtually all politicians will milk the spoils of division for what they are worth. Writing about the role of tribalism in American politics, Peter Morici tells us:

[V]oters still choose political parties and candidates based on social identities and adjust perceptions of facts on the ground and policy prescriptions to match party loyalties...

Few voters have time to understand the machinations of economics and government policy, and they rely on leaders who share their values to guide their thinking. The trick to winning elections consistently is to build a big tribe and then persuade enough of the 15 million swing voters with expensive data analytics. Those profile individuals through surveys, purchases and websurfing habits and then bombard them with surgically targeted social media messaging, videos, direct mail and walk and phone contact for registration, persuasion and turnout...

To build a tribe in an ethnically diverse, gender roleevolving, post-industrial America, parties must eschew binary divisions like workers vs. management but instead pick big villains that can unite a more fragmented electorate (Morici 2019).

The playbook on winning elections through manipulation has now been adapted for use in virtually all countries that have some form of democratic elections and this relies heavily on being able to push the electorate into narrow and harsh binaries that upend decades of social cohesion and coexistence. As Morici suggests, there is a need to unite the electorate around what he calls 'big villains' — which are adaptations over fears of 'the other' (notably Muslims and immigrants) as well as pandering to a dislike to large corporate power (a key theme that the US Democratic party perhaps disingenuously sells). In Europe, the immigrant question has been at the centre of national politics in several countries and has upended the traditional political process in ways from which it might never recover. In several African countries, hostility to outsiders is increasingly a factor in national politics and this coupled with a growth in evangelical Christianity is opening a new fault line in that intra-faith tensions, particularly with Islam are on the rise and could potentially upset fragile coexistence. This is not helped for instance, by the fact that insurgencies such as Boko Haram in Nigeria, or the Al Shabab incursions into Kenya have not been taken well by the Christian populations in these countries. In India, we have just seen the Hindu Nationalist government roll out a new citizenship law that will ostensibly render millions of Muslims stateless. The brutal campaign against the Rohingya Muslims in Myanmar that saw many thousands of them driven into exile and/or murdered was also fueled in large part by the use of social media, particularly Facebook.

Writing in the Economist Group's annual publication 'The World in 2020', Gideon Rachman contends that we should brace ourselves for a coming surge of separatism and that this will not necessarily lead to benign outcomes. $\mathrm{He}$ tells us that:

Across the world, two types of identity-driven movements are increasingly clashing - and feeding off each other. On the one hand, there are separatist groups that seek to break away from their nation-state and establish new countries; on the other, there is the outraged and assertive nationalism of existing states, determined to crush separatism. ${ }^{1}$

To the extent that separatism is spreading, it is relying to a great degree on driving deeper wedges into questions of identity (or identities) and citizenship. Separatism cannot just be reduced to the issue of groups seeking autonomy from their nation state and to establish new countries, but also a process by which some kind of 'purity' is being sought through creating the conditions that would alienate all those who do not fit some design or idea of who belongs. Whether one considers the quest to crush political opposition by declaring all those who have contrary ideas aliens (Tanzania), or the search for a monolithic identities (India and China) whereby all those who do not fit the 'approved' identity are either rendered outsiders or sent for 're-education and re-orientation', or even that dangerous idea that the United States belongs to a white population that sees its power and influence threatened by the growth of other racial groups and hence is obliged to 'set things right' by undermining the rights of other groups to ensure continued supremacy.

Identity politics, as we have earlier observed, attempts to draw boundaries between 'insiders' and 'outsiders' and this consequentially impacts on how resources are allocated between various groups. This impacts negatively on inter-group relations and further undermines possibility for peaceful dialogue and coexistence. As politics becomes

\footnotetext{
${ }^{1}$ Rachman, Gideon: The coming surge of separatism; The World in 2020, https://theworldin.economist.com/edition/2020/article/17374/ coming-surge-separatism.
} 
increasingly abrasive and intolerant of differences, we must cast our thinking nets wider to understand that the phenomena that afflict our societies today do not operate in isolation.

In his article 'What does Identity have to do with Inequality', Peter Callero remarked:

All, economic systems, political institutions, and associated patterns of social inequality emerge from face-to-face interactions, and our most significant interactions demand the recognition and negotiation of identity categories. The identity labels of "homeless", "black", "woman", or "gay", for example, are not simply neutral words for classifying and talking about groups of people. Identity labels affect the way we think, they influence our understanding of self, they shape our perceptions of each other, they guide our plans for action; they are used to justify power, to establish public policy and to organize social change. To be sure, identity processes do not operate in isolation, and we should not forget that economic, cultural, and political systems are key to the production of inequality. But these larger social processes are themselves dependent upon our unique ability to name and label each other (Callero 2017).

It therefore behooves us to make visible the linkages between the continued proliferation of economic inequalities and the resurgence of toxic identity politics. However, we will also need to go further and begin to transform the structures that make both these phenomena possible. Let us not forget that in many respects, multidimensional inequalities are intrinsically linked to issues of identities as it is the same social groups tend to be at the bottom of the heap in terms of their economic, social and political rights. In this respect, there is also the need to recognize that we cannot exclude having a gendered analysis of how the discourse of identity (and inequalities) are playing out. As Wendy Harcourt, a former Editor of this journal reminds us:

It matters not only what gender you identify with, but also what class, race and religion you belong to, and how they intersect structurally and relationally. Diversity within gender acknowledges everyday realities where gender is one determinant of power relations. In order to understand gender, it is important to understand socialized sexual difference in a historically grounded manner in ways that enable policy to tackle the racialized, heterosexual social order that informs dominant development discourse. This requires that we consider the intersections of race, gender and class (and other physical, social, economic and cultural divisions) which determine whether individuals can access social and economic resources, exercise their reproductive rights, and how they can engage in political and cultural change processes (Harcourt 2018).

As several authors in this journal issue make explicit, the stakes have never been higher on issues around identity and citizenship. The quest for 'pure nations' as well as splitting legal hairs to define legal belonging in ways that displaces and renders millions homeless and stateless is advancing rapidly. For many of us, these might be events that are perhaps too distant and remote from our own realities and therefore not worthy of our attention. However, the emergent trends suggest that we cannot be too sure betting that the same fate might not befall us-after all, the temptations to rewrite citizenship/residency laws are apparently more widespread than we might want to admit.

All the authors have tackled the subject-in our viewwith great passion and clarity and shone a light on just how the concepts of identity and citizenship are being challenged and reshaped, for better or for worse in different parts of the world. Whilst the pendulum might be swinging more to the side of 'worse', they (authors) are also very clear in challenging us readers to think through the consequences of the situations that they have described, they also remind us that failing to act or being complacent is only emboldening those who would undermine the notions of community, of shared belonging and seek to create monolithic spaces (unrealistic in our view). We are also introduced to the dilemmas of managing societies in rapidly changing circumstances and the role that technology is expected to play. The Chinese experimentation with social scores presents an interesting set of challenges - if viewed from the prism of the leadership - and forces us to think about the complexity of managing a vast population and modernizing the institutions and systems that are involved.

If we departed the last century convinced that we had settled certain debates, we are being reminded once again that the ghosts of the past never remain interred for too long. And perhaps it is a bit naïve to expect that issues of identity and belonging can be subsumed and made tamer through greater interaction and cosmopolitanism. The big questions that we must grapple with are around issues of why these phenomena of discrimination and exclusion keep coming back to the fore of public life and how we could (or should) respond. Fundamentally, and at the end of the day, what we are seeing playing out is a clash of visions as to what consists of the ideal society. The ideal society should not and cannot be constructed on the shattered dreams and aspirations of individuals who have been discarded simply because their 'fit' was considered wrong on account of their gender, color, creed or any other element that might be considered inconvenient. 
Prejudice and irrationality, where they are practiced must be challenged at every turn and opportunity and given no comfort. We should not fear to call out and shame those who would use their privilege to incite violence and hardship on those segments of the population that do not fit whichever warped idea they spout in order to defend their position and privilege. On this matter, there can be little room for compromise-but even as we push back, we should work towards creating greater clarity around the root causes and driving forces that underwrite such prejudices and discrimination-and inevitably, we revert back to the economic.

Here, we would do well to recall the words of Martin Luther King, which he shared with us in his last published work:

Are we more concerned with the size, power and wealth of our society or with creating a more just society? The failure to pursue justice is not only a moral default. Without it social tensions will grow and the turbulence in the streets will persist despite disapproval or repressive action. Even more, a withered sense of justice in an expanding society leads to corruption of the lives of all Americans. All too many of those who live in affluent America ignore those who exist in poor America; in doing so, the affluent Americans will eventually have to face themselves with the question that Eichmann chose to ignore: how responsible am I for the well-being of my fellows? To ignore evil is to become an accomplice to it (King Jr. 1968: 90-91).

Much as Dr. King was referring to the United States of his time, at the end of the 1960s, the challenge that he issues to us transcends both the territory and the epoch to make it universal and timeless. If we were to substitute his reference to America with our countries, do his remarks still retain their relevance? What then does this tell us?

This journal issue hopes to expand the space for dialogue around the issues of identity and citizenship, particularly as they might apply in our current context. Our societies are increasingly cosmopolitan and it highly unlikely that clocks can be turned back to a period when they were less so. The challenges that we face as we look ahead are myriad, but so are the opportunities. If we are to succeed collectively, it is because we manage to contextualize the challenges that we face and we are able to put together appropriate responses that not only valorize the collective value of society as a whole, but also open new pathways for us to explore and to build upon. That said, it would be foolish to pretend that this journal will have the final word on the subject. Nor can we expect that it will be immune from criticism-however, in the spirit of dialogue and conversation, additional contributions to the debate as well as constructive criticism are welcome. But even as we do so, it is perhaps wise to recall the words of Dr. Martin Luther King once again:

We must rapidly begin the shift from a "thing"-oriented society to a "person"-oriented society. When machines and computers, profit motives and property rights are considered more important than people, the giant triplets of racism, materialism and militarism are incapable of being conquered. A civilization can flounder as readily in the face of moral and spiritual bankruptcy as it can through financial bankruptcy (King Jr. 1968: 196-197).

We have a choice ahead of us: we can choose to be silent and let our societies be further divided by the mandarins that control us as they seek to extend their grasp, using new technologies and old hatreds to set us up against one another, or we can choose a path through which we explore and celebrate our diversity as a source of strength. This latter path is neither going to be straightforward nor easy, but it is necessary as the alternative is to choose a future of hostility and inevitably conflict from which there is little to gain and much to be lost. As we move forward, we will need to find the spaces and the courage to interrogate the assumptions that have led us to where we are today. In order to do so, we will need to establish new narratives, or stories to try and stoke our collective imaginations to describe a new set of paradigms that build bridges between communities and societies rather than dismantle them or erect walls across them. As John Powell wrote:

The stories we collectively hold are an important part of how we respond and will help determine whether our responses will be up to the task. Leaders play an oversized role in helping to give energy and meaning to the stories we tell ourselves and each other. This impacts not just how we see the world but also our actions in the world... the stories that we live by... promote belonging or othering. While rapid change may be an adequate explanation for our increased anxiety, it does not by itself explain the deep polarization and fear that are sweeping the world. Natural anxiety and stress can become either productive or hateful. Our possible responses are largely influenced by the stories we inhabit (Powell 2020).

Powell's article touches on many interesting points that are salient to our debate on identity and belonging, notably how history and the past are being used to fuel anxiety about the future and hence fears about the other. We can see, for instance, examples of such interpretation playing out in the politics of the Trump and Modi administrations in the United States and India. Yet, at the centre of the stories that are told to justify the paths being taken is a biased reading and 
understanding of history. In this respect, it might make sense to reflect on the words of Markha Valenta, who writing about how such ahistorical analyses corrupt our understanding of the present. She says:

This ideal of carefully screened-off cultural bubbles envisioned for the future has been complemented by an enabling historical myopia, as the same ideal has been read back into the past. While the Holocaust has increasingly been taken as the foundational trauma for the whole of western Europe-a shared inheritance enabling an overarching moral project-colonialism has been approached from the opposite perspective. Notwithstanding that at one point $85 \%$ of the world was under European control-affecting the economics, ideologies, politics, consumption, and cultures of all Europe and all non-Europe along the way-colonialism nonetheless has been seen as a matter of purely national significance, to be dealt with individually as each nation and state might occasionally see fit. One major misleading effect is that non-western immigrants are now largely imagined to be encountering Europe for the first time and to be bringing with them a purely alien culture untouched by decades and centuries under European control and influence. It is as if Europe had never gone out into the world in any significant cultural fashion, but only economically and militarily, while its own cultures were somehow left magically untouched... This sustains the notion of immigration as a quasi-apocalyptic cultural encounter without precedent that threatens to tear apart the continent and its people. So, while the Holocaust unites Europe and sustains its projection of itself into the world via a universalist project for human rights, the narrative of colonialism is divided along national lines and remains irrelevant both to official moral sensibility and to the European project at large. Colonialism is thereby 'historicized' in the worst sense of the word as something so far away in space and time that it can sustain a widespread conceit that those arriving from distant shores bring with them cultures and worlds far removed both from our European history and from our 'present'. Nothing could be further from the truth (Valenta 2010).
As such, our challenge-as has been suggested earlier, is that of creating new spaces to allow us to share, appreciate and integrate the various narratives to inform our collective belonging. Identities will never be static and in our discourse and analysis, we need to appreciate this fact and be open to understanding how the various identities interact and the extent to which their interactions are virtuous. In the final analysis, when all is said and done, we all belong here on this planet Earth and we could do worse than learning to live together and to share in what it has to offer.

\section{References}

Callero, Peter L. 2017. What does identity have to do with inequality? Psychology Today, 15 October, https://www.psychologytoday .com/us/blog/identity-and-inequality/201710/what-does-identityhave-do-inequality. Accessed 16 January 2020.

Harcourt, Wendy. 2018. Gender and Development: Looking Back, Looking Forward. Development 61: 9-13.

King Jr., Martin Luther. 1968. Where Do We Go from Here: Chaos or Community?, Kindle Edition. Boston: Beacon Press.

Morici, Peter. 2019. How tribalism corrupts our democracy. Deseret News, 29 December, https://www.deseret.com/opini on/2019/12/29/21038342/how-tribalism-corrupts-our-democracyrepublican-election-elizabeth-warren. Accessed 16 January 2020.

Polgreen, Lydia. 2019. The collapse of the information ecosystem poses profound risks for humanity. The Guardian, 19 November, https://www.theguardian.com/commentisfree/2019/nov/19/ the-collapse-of-the-information-ecosystem-poses-profound-risks -for-humanity. Accessed 16 January 2020.

Powell, John A. 2020. Bridging or Breaking? The Stories We Tell Will Create the Future We Inhabit. Non-Profit Quarterly, 14 January 2020, https://nonprofitquarterly.org/bridging-or-breaking-the-stori es-we-tell-will-create-the-future-we-inhabit. Accessed 16 January 2020.

Valenta, Markha. 2010. The success of Islamophobia. Open Democracy, 30 September, https://www.opendemocracy.net/en/succe ss-of-islamophobia/. Accessed 16 January 2020.

Publisher's Note Springer Nature remains neutral with regard to jurisdictional claims in published maps and institutional affiliations. 